\title{
KEMAMPUAN KOMUNIKASI MATEMATIKA SISWA SMP DALAM MENYELESAIKAN SOAL CERITA DITINJAU DARI TIPE KEPRIBADIAN
}

\author{
Mutamima \\ Pendidikan Matematika, Fakultas Matematika dan Ilmu Pengetahuan Alam, Universitas Negeri Surabaya, \\ mutamimabm@mhs.unesa.ac.id \\ Janet Trineke Manoy \\ Pendidikan Matematika, Fakultas Matematika dan Ilmu Pengetahuan Alam, Universitas Negeri Surabaya,
}

Abstrak

Tujuan penelitian ini adalah mengetahui kemampuan komunikasi matematika siswa. Dengan mengetahui kemampuan komunikasi matematika siswa, guru bisa memilih metode pembelajaran yang cocok untuk masing-masing tipe kepribadian. Penelitian ini merupakan penelitian deskriptif dengan pendekatan kualitatif. Data ini dikumpulkan menggunakan tes. Subjek dalam penelitian ini terdiri dari empat siswa yang diperoleh dari tes tipe kepribadian. Empat siswa tersebut terdiri dari satu siswa sanguinis, satu siswa koleris, satu siswa melankolis, dan satu siswa phlegmatic dan mempunyai kemampuan matematika setara. Selanjutnya siswa diberikan tes soal cerita untuk dianalisis sesuai dengan indikator kemampuan komunikasi matematika. Hasil analisis data dari penelitian ini yaitu (1) kemampuan komunikasi matematika tulis siswa SMP dalam menyelesaikan soal cerita dengan kepribadian sanguinis yaitu akurat, tidak lengkap, dan tidak lancar (2) kemampuan komunikasi matematika tulis siswa SMP dalam menyelesaikan soal cerita dengan kepribadian koleris yaitu tidak akurat, tidak lengkap, dan tidak lancar (3) kemampuan komunikasi matematika tulis siswa SMP dalam menyelesaikan soal cerita dengan kepribadian melankolis yaitu akurat, lengkap, dan lancar (4) kemampuan komunikasi matematika tulis siswa SMP dalam menyelesaikan soal cerita dengan kepribadian phlegmatic yaitu akurat, tidak lengkap, dan tidak lancar.

Kata Kunci: kemampuan komunikasi matematika, soal cerita, tipe kepribadian

\begin{abstract}
The purpose of this research was to know the ability to communicate mathematics students. By knowing the ability to communicate mathematics students, Teachers to be able to choose a method of learning suitable for each personality type. The research was descriptive research with a qualitative approach. This data collected use test. A subject in this research consisted of four students who obtained of a test personality type. Four students consisted of one student sanguine, one student choleric, one student, melancholy and one student phlegmatic have the ability and equivalent mathematics. Next students given tests about a story to analyzed the ability to communicate in accordance as those mathematics. The results of data analysis from this study were (1) mathematical communication ability written by junior high school students in solving story problems with sanguine personality, namely accurate, incomplete and not smooth (2) mathematical communication ability written by junior high school students in solving story problems with choleric personality ie no accurate, incomplete and not smooth (3) mathematical communication ability written by junior high school students in solving story problems with melancholic personality that is accurate, complete, and smooth (4) mathematical communication ability written by middle school students in solving story problems with phlegmatic personality, which is accurate, incomplete, and not smooth.
\end{abstract}

Keywords: mathematical communication ability, story problems, personality types.

\section{PENDAHULUAN}

Kemampuan komunikasi seseorang akan menentukan potensi sesesorang dalam berinteraksi dengan lingkungannya karena dengan memahami dan memperbaiki komunikasi yang dilakukan dapat meningkatkan hubungan sesama manusia. Penelitian Lovenidiana (2014) menunjukkan bahwa dalam proses pembelajaran kemampuan berkomunikasi siswa juga berpengaruh terhadap hasil belajar matematika di sekolah. Pendapat ini juga diperkuat oleh Mundy, et al (2000: 60), dijelaskan bahwa komunikasi merupakan bagian esensial dari matematika.
Matematika merupakan bahasa yang dapat digunakan untuk berkomunikasi. Dewi (2009) menyatakan bahwa matematika merupakan bahasa karena matematika adalah sekumpulan bahasa simbol yang mempunyai makna. Salah satu kemampuan yang harus dimiliki siswa dalam standar kurikulum 2013 yaitu kemampuan komunikasi. Mundy, et al (2000) juga menjelaskan bahwa setiap siswa memiliki kemampuan menggunakan matematika sebagai alat komunikasi.

Dalam lampiran peraturan menteri pendidikan No.58 tahun 2014 tentang kurikulum 2013 SMP dijelaskan bahwa keterampilan atau kepandaian matematika merupakan bagian dari keterampilan hidup yang harus dimiliki siswa 
terutama dalam mengembangkan penalaran, komunikasi, dan pemecahan masalah-masalah yang dihadapi siswa dalam kehidupan sehari-hari. Oleh sebab itu, maka kemampuan komunikasi sangat penting dikembangkan dalam pembelajaran matematika.

Menurut Dewi (2009) dalam pembelajaran matematika, masalah matematika dapat digunakan untuk melihat kemampuan komunikasi matematika siswa. Hal tersebut terjadi karena dalam menyelesaikan masalah siswa perlu mengkomunikasikan apa yang ada dalam pikirannya agar dapat dipahami oleh guru maupun siswa lain. Mundy, et al (2000) menjelaskan bahwa komunikasi merupakan salah satu dari lima standar proses yang ditekankan dalam NCTM (The National Council of Teachers Of Mathematics) yang meliputi pemecahan masalah (problem solving), penalaran dan bukti (reasoning and proof), komunikasi (communication), koneksi (connections), dan representasi (representation). Selain komunikasi matematika pemecahan masalah juga termasuk standar proses dari NCTM. Masalah matematika biasanya dapat disajikan ke dalam bentuk soal cerita. Menurut (Fitria, 2013 ) soal cerita adalah soal berbentuk cerita yang berkaitan dengan kehidupan sehari-hari siswa. Selanjutnya Romadhina (2007) berpendapat bahwa terdapat keterkaitan antara komunikasi matematika dengan kemampuan menyelesaikan soal cerita. Dalam menyelesaikan soal cerita, siswa akan diminta untuk mengubah soal ke dalam bentuk model matematika. Berdasarkan beberapa pendapat,, soal cerita yang digunakan dalam penelitian ini yaitu soal yang berbentuk cerita serta berhubungan dengan kehidupan sehari-hari.

Menurut Littauer (2003), ciri-ciri yang membedakan antara pribadi manusia itu merupakan perpaduan gen sifat dari keluarga kedua orang tuanya. Sementara Sujanto (dalam Purnaningsih, 2014), berpendapat bahwa kepribadian merupakan suatu susunan yang kompleks dari individu. Setiap kepribadian dalam diri manusia biasanya akan tampak dari tingkah lakunya. Dalam perkembangannya, kepribadian seseorang dipengaruhi oleh beberapa faktor sehingga menunjukkan sifat-sifat yang khas bagi setiap individu. Sifat-sifat khas yang ada dalam seseorang tersebut yang menggolongkan manusia menjadi empat tipe, yaitu Sanguinis, Koleris, Melankolis, dan Phlegmatis (Suryabrata, 2011). Setiap perbedaan kepribadian ini, memiliki kemampuan yang berbeda pula salah satunya dalam kemampuan komunikasi. Kemampuan setiap siswa dalam menyelesaikan soal cerita dipengaruhi oleh kemampuan komunikasi setiap siswa. Hal ini menunjukkan bahwa perbedaan kepribadian yang dimiliki siswa mempengaruhi kemampuan komunikasi siswa, termasuk dalam menyelesaikan soal cerita.

Menurut Kusuma (2009), kemampuan komunikasi matematika merupakan kemampuan yang ditunjukkan siswa dalam menyelesaikan masalah matematika. Komunikasi matematika dibedakan menjadi dua, yaitu komunikasi matematika lisan dan tertulis. Selanjutnya Dewi (2009) menyatakan bahwa komunikasi matematika tulis adalah proses penyampaian ide atau pikiran yang disampaikan dalam bentuk tulisan. Sedangkan komunikasi matematika lisan adalah proses penyampaian ide atau pikiran matematika yang disampaikan dalam bentuk ucapan. Dalam penelitian ini kemampuan komunikasi matematika siswa yang digunakan dibatasi pada kemampuan komunikasi matematika secara tertulis.

Berdasarkan penjelasan di atas, sehingga peneliti berkeinginan untuk melakukan penelitian yang bejudul "Kemampuan Komunikasi Matematika Siswa SMP Dalam Menyelesaikan Soal Cerita Ditinjau Dari Tipe Kepribadian (Sanguinis, Koleris, Melankolis, Dan Phlegmatis)

Tujuan Penelitian ini yaitu untuk mendeskripsikan (1) Kemampuan komunikasi matematika tulis siswa SMP dalam menyelesaikan soal cerita dengan tipe kepribadian sanguinis (2) Kemampuan komunikasi matematika tulis siswa SMP dalam menyelesaikan soal cerita dengan tipe kepribadian melankolis (3) Kemampuan komunikasi matematika tulis siswa SMP dalam menyelesaikan soal cerita dengan tipe kepribadian koleris (4) Kemampuan komunikasi matematika tulis siswa SMP dalam menyelesaikan soal cerita dengan tipe kepribadian phlegmatis.

\section{Kemampuan Komunikasi Matematika}

Menurut Mundy, et al (2000) kemampuan komunikasi matematika merupakan kemampuan siswa dalam menggunakan matematika sebagai alat komunikasi dan mengkomunikasikan matematika yang telah dipelajari. Dalam penelitian ini komunikasi matematika yang dimaksud proses penyampaian ide, gagasan, atau pendapat Matematika secara tertulis.

\section{Soal Cerita}

Dalam matematika, soal cerita merupakan soal yang berbentuk cerita yang biasanya berkaitan dengan kehidupan sehari-hari. Menurut Aulia (2015: 12)“soal cerita matematika adalah soal-soal matematika yang dinyatakan dalam kalimat-kalimat bentuk cerita dan perlu diterjemahkan menjadi model matematika atau kalimat matematika". Selanjutnya Istiqomah (2014: 21) mengartikan" soal cerita adalah modifikasi soal hitungan dalam bentuk verbal (cerita) yang diangkat dari kehidupan sehari-hari serta di dalamnya terkandung masalah yang berkaitan dengan konsep matematika". Sehingga berdasarkan beberapa pengertian soal cerita di atas, soal cerita merupakan soal matematika yang berbentuk cerita dan berhubungan dengan kehidupan sehari-hari.

\section{Tipe Kepribadian}


Tipe kepribadian yang digolongkan Galenus meliputi Sanguinis, Koleris, Melankolis, dan Phlegmatis.

\section{Sanguinis (Sanguine)}

Menurut Littauer (2003) orang dengan tipe kepribadian sanguinis merupakan kepribadian yang ceria, suka bergembira-ria, supel, dan membuat kebanyakan orang tertarik dengan sikapnya yang periang. Mereka cenderung terlalu banyak bicara, humoris, dan kreatif.

\section{Melankolis (Melancholy)}

Bertolak belakang dengan kebanyakan orang dengan kepribadian sanguinis yang suka bergembira-ria, justru orang-orang yang berkepribadian melankolis yakni orangorang yang pemikir, introspektif, serius, dan perfeksionis. Mereka sulit untuk disalahkan karena mereka selalu merasa melakukan segalanya dengan benar dan dapat membuktikan bahwa masalah yang muncul merupakan akibat kesalahan orang lain.

\section{Koleris (Choleric)}

Tipe kepribadian melankolis merasa diri mereka benar, sedangkan orang-orang tipe kepribadian koleris yakin diri mereka benar. Bahkan ketika semua orang menentang ide mereka, orang-orang dengan kepribadian koleris ini akan tetap memaksakan kehendaknya. Penentangan justru membuat tekad mereka semakin kuat. Lelaki maupun perempuan, tua maupun muda, diprogram untuk lebih memaksakan kehendak sendiri dari pada berdamai dengan orang lain. Tidak ada gunanya berdebat dengan seorang koleris. Tidak akan ada yang menang melawan seorang koleris, namun dalam kelompok, seorang koleris cenderung menjadi presiden, menjadikan tugas-tugas terlaksana dengan cepat, dan tidak membuang-buang waktu dengan pembicaraan sia-sia. Mereka merupakan pemimpin-pemimpin dinamis.

\section{Phlegmatis (Plegmatic)}

Orang-orang berkepribadian koleris kuat kemauannya, sedangkan orang-orang dengan tipe kepribadian phlegmatis, akan selalu menuruti mereka dan tidak tidak akan membantah. Bukan karena seorang phlegmatis itu bodoh, justru dialah yang paling cerdas di antara yang lain. Mereka tahu bahwa kepribadian yang manis, yang menyenangkan, akan menghipnotis orang lain mengerjakan pekerjaan mereka. Seorang phlegmatis lebih memilih untuk menghemat energi dan merasa bahwa jika ia mengabaikan suatu pekerjaan cukup lama, akan ada orang lain yang akan menyelesaikan. Mereka santai dan diplomatis, tetapi tidak cukup cepat bagi kebanyakan orang yang berkepribadian koleris. seorang phlegmatis tidak suka resiko, tantangan, dan kejutan, dan akan membutuhkan waktu lebih lama untuk beradaptasi terhadap perubahan.

\section{Komunikasi Matematika dalam Menyelesaikan Soal Cerita}

Dalam menyelesaikan soal cerita, siswa perlu mengkomunikasikan ide-ide yang ada dalam kepalanya agar dapat dipahami oleh guru atau siswa lain.

\section{Kemampuan Komunikasi Matematika dan Kepribadian}

Kemampuan komunikasi matematika sangat erat hubungannya dengan kepribadian. Kepribadian siswa yang berbeda-beda akan mengakibatkan kemampuan komunikasi matematika siswa akan berbeda-beda pula. Komunikasi amat esensial untuk pertumbuhan kepribadian manusia. Ahli-ahli ilmu sosial telah berulang kali mengungkapkan bahwa kurangnya komunikasi akan menghambat perkembangan kepribadian manusia. Dari ungkapan tersebut disimpulkan bahwa kemampuan komunikasi matematika juga mempengaruhi kepribadian suatu individu, karena matematika mempunyai nilai-nilai yang dapat membentuk karakter seseorang.

\section{METODE}

Penelitian ini merupakan penelitian deskriptif dengan pendekatan kualitatif. penelitian ini bertujuan untuk mendeskripsikan kemampuan komunikasi matematika siswa dalam menyelesaikan soal cerita ditinjau dari tipe kepribadian. Penelitian ini mendeskripsikan kemampuan komunikasi matematika dari masing-masing tipe kepribadian yaitu sanguinis, koleris, melankolis, dan phlegmatis. Pengambilan data dilakukan di kelas VIII SMP. Subjek dalam penelitian ini yaitu empat siswa kelas VIII yang telah menerima materi SPLDV. Subjek penelitian dipilih berdasarkan hasil tes kepribadian. Subjek terdiri dari satu siswa sanguinis, satu siswa koleris, satu siswa melankolis dan satu siswa phlegmatis yang masingmasing memiliki kemampuan matematika yang setara berdasarkan rekomendasi dari guru matematika.

Instrumen yang digunakan pada penelitian ini yaitu tes tipe kepribadian dan tes soal cerita. Pengumpulan data dimulai dengan memberikan tes tipe kepribadian terlebih dahulu. Setelah keempat subjek diperoleh selanjutnya diberikan tes soal cerita.

Data tentang tipe kepribadian siswa diperoleh dari tes tipe kepribadian dimana penyusunan butir-butir penyataan pada tes diadaptasi dari Littauer (2003). Data tentang kemampuan komunikasi matematika untuk masing-masing tipe kepribadian diperoleh dari tes soal cerita yang diadaptasi dari soal UN tahun 2015 dan 2016. Soal UN yang berupa soal pilihan ganda dalam tes ini diadaptasi menjadi soal uraian, sehingga siswa harus mengerjakannya berikut dengan langkah-langkah penyelesaiannya. Soal Tes Kemampuan Komunikasi Matematika Tulis yang digunakan terdiri dari tiga soal dengan materi SPLDV. Soal yang diberikan kepada subjek sebelumnya telah 
dikonsultasikan terlebih dahulu dengan dosen pembimbing untuk mendapatkan soal yang valid.

Dalam penelitian ini, data tipe kepribadian yang dianalisis diperoleh dari hasil tes tipe kepribadian yang diberikan pada siswa. Data dianalisis berdasarkan langkahlangkah berikut.

a. Merekapitulasi hasil pilihan jawaban siswa pada setiap nomor.

b. Menghitung jumlah pilihan jawaban siswa pada setiap nomor

Jika siswa memilih paling banyak pilihan a, maka siswa termasuk tipe kepribadian sanguinis, jika siswa paling banyak pilihan $b$, maka siswa bertipe kepribadian koleris, jika siswa paling banyak pilihan c maka siswa bertipe kepribadian melankolis, jika siswa paling banyak pilihan $\mathrm{d}$ maka siswa bertipe kepribadian phlegmatis, dan bertipe kepribadian kombinasi apabila ada dua pilihan terbanyak.

Proses menganalisis data tes soal cerita yang diperoleh digunakan beberapa teknik analisis data sebagai berikut.

a. Memeriksa data hasil tes pekerjaan dari keempat subjek terpilih.

b. Mereduksi data

Setelah memeriksa data yang diperoleh dari tes soal cerita kemudian dilakukan reduksi data. Reduksi data adalah kegiatan yang berupa proses pemilihan, penyederhanaan, pemusatan perhatian, pengabstraksian, dan transformasi mentah di lapangan. Hal ini dimaksudkan untuk menyingkirkan yang tidak perlu, menggolongkan, dan mengorganisasikan data mentah yang diperoleh di lapangan. Menganalisis hasil tes berdasarkan indikator kemampuan komunikasi matematika tulis.

c. Memaparkan data

Pemaparan data meliputi pengklasifikasian dan identifikasi data, yaitu menuliskan kumpulan data yang terorganisir atau pembahasan terhadap data dengan mengacu pada indikator-indikator yang telah ditetapkan sehinggga memungkinkan untuk menarik kesimpulan dari data tersebut.

d. Menarik kesimpulan

Data yang sudah dipaparkan dan dibahas secara jelas kemudian ditarik kesimpulan dari data tersebut mengenai "kemampuan komunikasi matematika siswa SMP dalam menyelesaikan soal cerita matematika ditinjau dari tipe kepribadian (sanguinis, koleris, melankolis, dan phlegmatis)"

\section{HASIL DAN PEMBAHASAN}

Hasil

Kemampuan komunikasi matematika tulis siswa SMP dalam menyelesaikan soal cerita dengan tipe kepribadian sanguinis (S1).

Berdasarkan indikator keakuratan, pada tahap memahami masalah S1 disimpulkan akurat karena S1 menuliskan hal-hal yang diketahui dan yang ditanya dengan benar. Pada tahap membuat rencana penyelesaian S1 disimpulkan akurat karena menuliskan model matematika dengan benar dan menuliskan rumus/ atau metode matematika dengan benar. Pada tahap melaksanakan penyelsaian S1 disimpulkan akurat karena menuliskan perhitungan matematika dengan benar. Pada tahap meninjau kembali S1 disimpulkan akurat karena menuliskan kesimpulan dengan benar sesuai yang diminta soal.

Berdasarkan indikator kelengkapan, pada tahap memahami masalah S1 disimpulkan tidak lengkap karena S1 menuliskan hal-hal yang diketahui dan yang ditanya kurang lengkap. Pada tahap membuat rencana penyelesaian S1 disimpulkan lengkap karena S1 menuliskan model matematika dan rumus/ metode matematika dengan benar dan lengkap sesuai yang dibutuhkan. Pada tahap melaksanakan penyelesaian, S1 disimpulkan lengkap karena melakukan perhitungan dengan benar dan lengkap, tidak ada yang tertinggal. Pada tahap meninjau kembali S1 disimpulkan lengkap karena S1 menuliskan kesimpulan dengan benar dan lengkap sesuai dengan yang diminta soal.

Berdasarkan indikator kelancaran, pada tahap memahami masalah S1 disimpulkan tidak lancar karena S1 menuliskan hal-hal yang diketahui dan ditanya dengan benar namun tidak lengkap dan adanya coretan karena salah tulis. Pada tahap membuat rencana penyelesaian S1 disimpulkan lancar karena S1 menuliskan semua model matematika dan rumus/ metode matematika yang diperlukan dalam soal dengan benar dan tidak ada yang tertinggal serta tanpa ada coretan karena salah tulis. Pada tahap melaksanakan penyelesaian S1 disimpulkan lancar karena S1 menuliskan semua perhitungan dengan benar dan tidak ada yang tertinggal sesuai yang dibutuhkan soal, serta tanpa ada coretan karena salah tulis. Pada tahap meninjau kembali S1 disimpulkan lancar karena S1 menuliskan kesimpulan dengan benar sesuai yang diminta soal dan tanpa ada coretan karena salah tulis.

Kemampuan komunikasi matematika tulis siswa SMP dalam menyelesaikan soal cerita dengan tipe kepribadian koleris (S2).

Berdasarkan indikator keakuratan, pada tahap memahami masalah S2 disimpulkan akurat karena S2 menuliskan hal-hal yang diketahui dan yang ditanya dengan benar. Pada tahap membuat rencana penyelesaian S2 disimpulkan tidak akurat karena menuliskan model matematika dengan benar namun menuliskan rumus/ atau metode matematika dengan salah. Pada tahap melaksanakan penyelsaian S2 disimpulkan tidak akurat karena menuliskan perhitungan matematika dengan salah. Pada tahap meninjau kembali S2 disimpulkan tidak akurat karena menuliskan kesimpulan dengan salah. 
Berdasarkan indikator kelengkapan, pada tahap memahami masalah S2 disimpulkan tidak lengkap karena S2 menuliskan hal-hal yang diketahui dan yang ditanya kurang lengkap. Pada tahap membuat rencana penyelesaian S2 disimpulkan tidak lengkap karena S2 menuliskan model matematika dan rumus/ metode matematika dengan tidak benar dan lengkap sesuai yang dibutuhkan. Pada tahap melaksanakan penyelesaian, S2 disimpulkan tidak lengkap karena melakukan perhitungan dengan tidak benar dan lengkap, tidak ada yang tertinggal. Pada tahap meninjau kembali S2 disimpulkan tidak lengkap karena S2 menuliskan kesimpulan dengan tidak benar dan lengkap sesuai dengan yang diminta soal.

Berdasarkan indikator kelancaran, pada tahap memahami masalah S2 disimpulkan tidak lancar karena S2 menuliskan hal-hal yang diketahui dan ditanya dengan benar namun tidak lengkap dan adanya coretan karena salah tulis. Pada tahap membuat rencana penyelesaian S2 disimpulkan tidak lancar karena S2 menuliskan model matematika dan rumus/ metode matematika yang diperlukan dalam soal dengan tidak benar walaupun tanpa ada coretan karena salah tulis. Pada tahap melaksanakan penyelesaian S2 disimpulkan tidak lancar karena S2 menuliskan salah satu perhitungan dengan salah walaupun tanpa ada coretan karena salah tulis. Pada tahap meninjau kembali S2 disimpulkan lancar karena S2 menuliskan kesimpulan dengan benar sesuai yang diminta soal dan tanpa ada coretan karena salah tulis.

Kemampuan komunikasi matematika tulis siswa SMP dalam menyelesaikan soal cerita dengan tipe kepribadian melankolis (S3).

Berdasarkan indikator keakuratan, pada tahap memahami masalah S3 disimpulkan akurat karena S3 menuliskan halhal yang diketahui dan yang ditanya dengan benar. Pada tahap membuat rencana penyelesaian S3 disimpulkan akurat karena menuliskan model matematika dengan benar dan menuliskan rumus/ atau metode matematika dengan benar. Pada tahap melaksanakan penyelsaian S3 disimpulkan akurat karena menuliskan perhitungan matematika dengan benar. Pada tahap meninjau kembali S3 disimpulkan akurat karena menuliskan kesimpulan dengan benar sesuai yang diminta soal.

Berdasarkan indikator kelengkapan, pada tahap memahami masalah S3 disimpulkan lengkap karena S3 menuliskan hal-hal yang diketahui dan yang ditanya dengan lengkap tanpa ada yang tertinggal. Pada tahap membuat rencana penyelesaian S3 disimpulkan lengkap karena S3 menuliskan model matematika dan rumus/ metode matematika dengan benar dan lengkap sesuai yang dibutuhkan. Pada tahap melaksanakan penyelesaian, S3 disimpulkan lengkap karena melakukan perhitungan dengan benar dan lengkap, tidak ada yang tertinggal. Pada tahap meninjau kembali S3 disimpulkan lengkap karena S3 menuliskan kesimpulan dengan benar dan lengkap sesuai dengan yang diminta soal.

Berdasarkan indikator kelancaran, pada tahap memahami masalah S3 disimpulkan lancar karena S3 menuliskan hal-hal yang diketahui dan ditanya dengan benar namun tidak lengkap dan adanya coretan karena salah tulis. Pada tahap membuat rencana penyelesaian S3 disimpulkan lancar karena S3 menuliskan semua model matematika dan rumus/ metode matematika yang diperlukan dalam soal dengan benar dan tidak ada yang tertinggal serta tanpa ada coretan karena salah tulis. Pada tahap melaksanakan penyelesaian S3 disimpulkan lancar karena S3 menuliskan semua perhitungan dengan benar dan tidak ada yang tertinggal sesuai yang dibutuhkan soal, serta tanpa ada coretan karena salah tulis. Pada tahap meninjau kembali S3 disimpulkan lancar karena S3 menuliskan kesimpulan dengan benar sesuai yang diminta soal dan tanpa ada coretan karena salah tulis.

Kemampuan komunikasi matematika tulis siswa SMP dalam menyelesaikan soal cerita dengan tipe kepribadian phlegmatis.

Berdasarkan indikator keakuratan, pada tahap memahami masalah, S4 disimpulkan akurat karena S4 menuliskan hal-hal yang diketahui dan yang ditanya dengan benar. Pada tahap membuat rencana penyelesaian S4 disimpulkan akurat karena menuliskan model matematika dengan benar dan menuliskan rumus/ atau metode matematika dengan benar. Pada tahap melaksanakan penyelesaian S4 disimpulkan akurat karena menuliskan perhitungan matematika dengan benar. Pada tahap meninjau kembali, S4 disimpulkan tidak akurat karena tidak menuliskan kesimpulan diminta soal.

Berdasarkan indikator kelengkapan, pada tahap memahami masalah, S1 disimpulkan tidak lengkap karena S4 menuliskan hal-hal yang diketahui dan yang ditanya kurang lengkap. Pada tahap membuat rencana penyelesaian, S4 disimpulkan lengkap karena S4 menuliskan model matematika dan rumus/ metode matematika dengan benar dan lengkap sesuai yang dibutuhkan. Pada tahap melaksanakan penyelesaian, S4 disimpulkan lengkap karena melakukan perhitungan dengan benar dan lengkap, tidak ada yang tertinggal. Pada tahap meninjau kembali S4 disimpulkan tidak lengkap karena S4 tidak menuliskan kesimpulan yang diminta soal.

Berdasarkan indikator kelancaran, pada tahap memahami masalah, S4 disimpulkan tidak lancar karena S4 menuliskan hal-hal yang diketahui dan ditanya dengan benar namun tidak lengkap dan adanya coretan karena salah tulis. Pada tahap membuat rencana penyelesaian, S4 disimpulkan tidak lancar karena S4 menuliskan semua model matematika dan rumus/ metode matematika yang 
diperlukan dalam soal dengan benar dan tidak ada yang tertinggal namun ada coretan karena salah tulis. Pada tahap melaksanakan penyelesaian S1 disimpulkan lancar karena S1 menuliskan semua perhitungan dengan benar dan tidak ada yang tertinggal sesuai yang dibutuhkan soal, serta tanpa ada coretan karena salah tulis. Pada tahap meninjau kembali S1 disimpulkan tidak lancar karena S4 tidak menuliskan kesimpulan yang diminta soal.

\section{Pembahasan}

Kemampuan komunikasi matematika tulis siswa SMP dalam menyelesaikan soal cerita dengan tipe kepribadian sanguinis

Dalam tahap memahami masalah, siswa dengan kepribadian sanguinis pada semua indikator kemampuan komunikasi dalam menyelesaikan soal cerita disimpulkan akurat, tidak lengkap dan tidak lancar. Dalam tahap rencana penyelesaian masalah, siswa dengan kepribadian sanguinis pada semua indikator kemampuan komunikasi dalam menyelesaikan soal cerita disimpulkan akurat, lengkap, dan tidak lancar. Dalam tahap melakukan penyelesaian masalah, siswa dengan kepribadian sanguinis pada semua indikator kemampuan komunikasi dalam menyelesaikan soal cerita disimpulkan akurat, lengkap, dan tidak lancar. Dalam tahap meninjau kembali, siswa dengan kepribadian sanguinis pada semua indikator kemampuan komunikasi dalam menyelesaikan soal cerita disimpulkan akurat, lengkap, dan lancar

Kemampuan komunikasi matematika tulis siswa SMP dalam menyelesaikan soal cerita dengan tipe kepribadian koleris

Dalam tahap memahami masalah, siswa dengan kepribadian koleris pada semua indikator kemampuan komunikasi dalam menyelesaikan soal cerita disimpulkan akurat, tidak lengkap dan tidak lancar. Dalam tahap rencana penyelesaian masalah, siswa dengan kepribadian koleris pada semua indikator kemampuan komunikasi dalam menyelesaikan soal cerita disimpulkan tidak akurat, tidak lengkap, dan tidak lancar. Dalam tahap melakukan penyelesaian masalah, siswa dengan kepribadian koleris pada semua indikator kemampuan komunikasi dalam menyelesaikan soal cerita disimpulkan tidak akurat, tidak lengkap, dan tidak lancar. Dalam tahap meninjau kembali, siswa dengan kepribadian koleris pada semua indikator kemampuan komunikasi dalam menyelesaikan soal cerita disimpulkan tidak akurat, tidak lengkap, dan tidak lancar.

Kemampuan komunikasi matematika tulis siswa SMP dalam menyelesaikan soal cerita dengan tipe kepribadian melankolis

Dalam tahap memahami masalah, siswa dengan kepribadian melankolis pada semua indikator kemampuan komunikasi dalam menyelesaikan soal cerita disimpulkan akurat, lengkap dan lancar. Dalam tahap rencana penyelesaian masalah, siswa dengan kepribadian melankolis pada semua indikator kemampuan komunikasi dalam menyelesaikan soal cerita disimpulkan akurat, lengkap, dan lancar. Dalam tahap melakukan penyelesaian masalah, siswa dengan kepribadian melankolis pada semua indikator kemampuan komunikasi dalam menyelesaikan soal cerita disimpulkan akurat, lengkap, dan lancar. Dalam tahap meninjau kembali siswa dengan kepribadian melankolis pada semua indikator kemampuan komunikasi dalam menyelesaikan soal cerita disimpulkan akurat, lengkap, dan lancar.

Kemampuan komunikasi matematika tulis siswa SMP dalam menyelesaikan soal cerita dengan tipe kepribadian phlegmatis

Dalam tahap memahami masalah, siswa dengan kepribadian phlegmatis pada semua indikator kemampuan komunikasi dalam menyelesaikan soal cerita disimpulkan akurat, tidak lengkap dan tidak lancar. Dalam tahap rencana penyelesaian masalah, siswa dengan kepribadian phlegmatis pada semua indikator kemampuan komunikasi dalam menyelesaikan soal cerita disimpulkan akurat, lengkap, dan tidak lancar. Dalam tahap melakukan penyelesaian, masalah siswa dengan kepribadian phlegmatis pada semua indikator kemampuan komunikasi dalam menyelesaikan soal cerita disimpulkan akurat, lengkap, dan lancar. Dalam tahap meninjau kembali siswa dengan kepribadian melankolis pada semua indikator kemampuan komunikasi dalam menyelesaikan soal cerita disimpulkan tidak akurat, tidak lengkap, dan tidak lancar

\section{Diskusi}

Melalui penelitian ini, diperoleh hasil data tentang kemampuan komunikasi matematika siswa SMP dalam menyelesaikan soal cerita ditinjau dari tipe kepribadian (sanguinis, koleris, melankolis, dan phlegmatis. Namun masih terdapat kelemahan yaitu, pada soal yang diberikan tidak dituliskan langkah-langkah apa saja yang perlu digunakan untuk menyelesaikan soal cerita. Sehingga deskripsi kemampuan komunikasi matematika dalam menyelesaikan soal cerita kurang jelas. Seperti pada tahap memahami masalah, ketiga subjek menuliskan hal-hal yang diketahui dan ditanya dengan langsung menuliskan model matematikanya. Pada tahap meninjau kembali, tidak semua subjek menuliskan yang disimpulkan pada jawaban yang dibutuhkan dalam soal cerita. Hal ini dikarenakan peneliti tidak meminta subjek untuk memeriksa kembali jawaban mereka. Padahal meninjau kembali merupakan salah satu indikator dari kemampuan komunikasi matematika menyelesaikan soal cerita. 


\section{PENUTUP}

\section{Simpulan}

Berdasarkan analisis data dan pembahasan pada penelitian ini, dapat disimpulkan sebagai berikut.

1. kemampuan komunikasi matematika siswa SMP dalam menyelesaikan soal cerita dengan kepribadian sanguinis disimpulkan akurat, lengkap, dan tidak lancar

2. kemampuan komunikasi matematika siswa SMP dalam menyelesaikan soal cerita dengan kepribadian koleris disimpulkan tidak akurat, tidak lengkap, dan tidak lancar.

3. Sehingga kemampuan komunikasi matematika siswa SMP dalam menyelesaikan soal cerita dengan kepribadian melankolis disimpulkan akurat, lengkap, dan lancar.

4. kemampuan komunikasi matematika siswa SMP dalam menyelesaikan soal cerita dengan kepribadian phlegmatis disimpulkan akurat, tidak lengkap, dan tidak lancar.

\section{Saran}

Sehubungan dengan hasil yang telah dikemukakan dalam penelitian ini maka saran yang diajukan peneliti sebagai berikut:

1. Pada saat pemilihan subjek sebaiknya dilakukan tes kemampuan matematika, bukan hanya meminta rekomendasi dari guru matematika.

2. Untuk penelitian selanjutnya, siswa perlu diingatkan hal-hal apa saja yang perlu dilakukan agar jawaban tes soal cerita siswa sesuai indikator kemampuan komunikasi matematika.

\section{DAFTAR PUSTAKA}

Aulia, Kharitsa. 2015. Identifikasi Ketidakpahaman Siswa SMP Dalam Menyelesaikan Soal Cerita Aljabar. Skripsi. UNESA: tidak diterbitkan.

Dewi, Izwita. 2009. Profil Komunikasi Matematika Mahasiswa Ditinjau Dari Jenis Kelamin. Tesis. PPS UNESA: tidak diterbitkan.

Fitria, Titis N. 2013. Analisis Kesalahan Siswa Dalam Menyelesaikan Soal Cerita Berbahasa Inggris Pada Materi Persamaan Dan Pertidaksamaan Linear Satu Variabel. Skripsi. UNESA: tidak diterbitkan.

Istiqomah, Nurul. Proses Berpikir Siswa Smp Dalam Menyelesaikan Soal Cerita Matematika Berdasarkan Gaya Kognitif Pada Materi Bangun Ruang Sisi Lengkung. Skripsi. UNESA: tidak diterbitkan.

Littauer, Florence. 2003. Personality Plus For Couples. Jakarta: Binarupa Aksara.

Mundy, Joan Ferriny, et al. 2000. Principles and Standards For School Mathematics, Reston: Virginia. Online (http://www.nctm.org/standards/content.aspx?id=28 643) diakses 5 Juli 2016

Romadhina, Dian. 2007. Pengaruh Kemampuan Penalaran dan Kemampuan Komunikasi Matematik Terhadap Kemampuan Menyelesaikan Soal Cerita Pada Pokok Bahasan Bangun Ruang Sisi Lengkung Siswa Kelas IX SMP Negeri 29 Semarang Melalui Model Pembelajaran Pemecahan Masalah. Skripsi. UNNES: tidak diterbitkan.

Suryabrata, S. 2011. Psikologi Kepribadian. Jakarta: Rajagrafindo Persada. 